\title{
HUBUNGAN USIA, PARITAS DAN PERSONAL HYGIENE DENGAN HASIL PEMERIKSAAN INSPEKSI VISUAL ASAM ASETAT (IVA) DI PUSKESMAS BRANGSONG 2 KECAMATAN BRANGSONG KABUPATEN KENDAL
}

\author{
AGE RELATIONSHIP, PARITY AND PERSONAL HYGIENE DIAGNOSIS WITH IVA IN \\ PUSKESMAS BRANGSONG DISTRICT 2 DISTRICT BRANGSONG KENDAL
}

\author{
$\underline{\text { T.Ria Marriagewati M Adam }{ }^{1)}, \text { Dharminto }^{2)} \text {, Frida Cahyaningrum }}{ }^{3)}$ \\ ${ }^{1) 2) 3)}$ Akademi Kebidanan Abdi Husada Semarang \\ Email: ningfrida87@yahoo.com
}

\begin{abstract}
ABSTRAK
Kanker serviks adalah keganasan yang terjadi pada leher rahim tetapi terbentuknya sangat perlahan, kanker servik adalah kanker terbanyak kedua pada perempuan di Indonesia setelah kanker payudara. Ada beberapa faktor resiko yang menyebabkan kanker servik salah satunya seperti usia, hubungan seksual sejak usia muda, genetik, merokok, paritas, personal hygiene dan defisiensi zat gizi. Penelitian ini bertujuan untuk mengetahui hubungan usia, paritas dan personal hygiene dengan hasil pemeriksaan IVA. Penelitian ini merupakan penelitian deskriptif korelatif. Sampel terdiri dari 78 orang. Variabel bebas dalam penelitian ini meliputi usia, paritas dan personal hygiene dan variabel terikatnya hasil pemeriksaan IVA. Data dikumpulkan menggunakan kuesioner dan analisa menggunakan uji Chi Square pada tingkat kesalahan 0,05. Penelitian menunjukkan ada hubungan yang bermakna antara usia dengan hasil pemeriksaan IVA dengan signifikansi $(P)=0,00 ;$ ada hubungan yang bermakna antara paritas dengan hasil pemeriksaan IVA dengan signifikansi $(P)=0,05$; tidak ada hubungan antara personal hygiene dengan hasil pemeriksaan IVA dengan signifikansi $(P)=0,73$. Penelitian menunjukkan ada hubungan yang bermakna antara usia dengan hasil pemeriksaan IVA; ada hubungan yang bermakna antara paritas dengan hasil pemeriksaan IVA; tidak ada hubungan antara personal hygiene dengan hasil pemeriksaan IVA.
\end{abstract}

Kata Kunci : : Usia, Paritas, Personal Hygiene, Pemeriksaan IVA

\begin{abstract}
Cervical cancer is a malignancy that occurs in the cervix but formed very slowly, cervical cancer is the second largest cancer in women at Indonesia after breast cancer. There are several risk factors that cause cervical cancer one of them such as age, sex at a young age, genetics, smoking, parity, personal hygiene and nutritional deficiency. This study aims to determine the relationship of age, parity and personal hygiene with the results of the IVA. This study is a descriptive correlative study. Sample consisted of 78 womens. The independent variable in this study include age, parity and personal hygiene and the dependent variable results of IVA. Data were collected using questionnaires and analysis using Chi Square test at the 0.05 error level. The results showed no significant association between the age of the IVA with the results of significance $(P)=0.00$; there is a significant association between parity with the results of the IVA with significance $(P)=0.05$, there is no relationship between personal hygiene with IVA test results with significance $(P)=0.73$. The results showed no significant association between the age of the IVA; there is a significant association between parity with the results of the IVA, there is no relationship between personal hygiene with IVA.
\end{abstract}

Key Word : Age, Parity, Personal Hygiene, Results of the IVA

\section{PENDAHULUAN}

Kanker serviks merupakan jenis kanker terbanyak kedua pada wanita didunia dan menjadi penyebab lebih dari 250.000 kematian pada tahun 2005. Kurang lebih $80 \%$ kematian tersebut terjadi di negara berkembang.

Kanker serviks adalah kanker terbanyak pada perempuan di Indonesia dan peringkat kedua setelah kanker payudara pada perempuan di Asia Tenggara. Namun, kanker serviks juga menduduki peringkat pertama di Thailand, Myanmar, Laos dan Kamboja. Diperkirakan ada 39.800 kasus baru dan 20.600 angka kematian per tahun di regional ini pada tahun 1995. Di Indonesia terdapat 15.000 kasus baru dengan 8.000 kematian setiap tahunnya. Kanker ini merupakan 
kanker tersering pada perempuan Indonesia. Diperkirakan 1 orang perempuan meninggal setiap jam. Di Jakarta, setiap 1-2 hari, ada 1 orang perempuan yang meninggal karena kanker ini.

Data dari RSU dr. H. Soewondo Kabupaten Kendal penderita kanker serviks pada tahun 2013 sebanyak 84 penderita, tahun 2014 sebanyak 95 penderita, tahun 2015 sampai bulan juli ini sebanyak 73 penderita kanker servik.

Untuk mengurangi morbiditas dan mortalitas kanker serviks perlu upaya-upaya pencegahan, yang terdiri dari beberapa tahap, yaitu: 1. Pencegahan Primer yang dilakukan pada tahap ini adalah promosi, edukasi serta vaksinasi HPV (Human Papilloma Virus). 2. Pencegahan sekunder yaitu melakukan deteksi dini. 3. Pencegahan Tersier yaitu pengobatan untuk kasus yang ditemukan pada deteksi dini serta mencegah komplikasi dan kematian awal.

Deteksi dini di Indonesia dilakukan dengan tes pap smear, kolposkopi, gineskopi, servikografi, spekuloskopi, automated screening cytology, liquid based cytology / thin prep, tes HPV dan metode pameriksaan Inspeksi Visual Asam Asetat (IVA) (Nuranna, 2011b). Cakupan tes pap smear diperkirakan kurang dari 5\%. Untuk memenuhinya, diupayakan alternatif tes pap smear dengan IVA, yang diharapkan mendapatkan cakupan yang lebih luas.

Pemeriksaan IVA pertama kali diperkenalkan oleh Hinselman (1925). Metode pemeriksaan IVA adalah pemeriksaan yang dapat dilakukan oleh (dokter/bidan/paramedis) dengan cara mengamati serviks yang telah diberi asam asetat/asam cuka 3-5\% secara inspekulo / dilihat langsung dengan penglihatan mata langsung (mata telanjang) (nuranna, 2011a). Hasilnya langsung bisa didapat, dan sensitivitas cukup baik. Alat dan bahan yang dibutuhkan pun sangat sederhana, yaitu spekulum vagina, asam asetat 3-5\%, kapas lidi, meja pemeriksaan, sarung tangan bersih dan pencahayaan yang cukup terang.
Di Indonesia, IVA dapat menjadi metode alternatif untuk deteksi dini. Pertimbangan ini dibuat dengan alasan: mudah, murah, praktis dilaksanakan dan dapat dilakukan oleh tenaga kesehatan non dokter ginekologi, bahkan bidan ditempat terpencil.

Resiko menderita kanker serviks adalah wanita yang aktif berhubungan seks sejak usia sangat dini, sering berganti-ganti pasangan seks, menggunakan pil kontrasepsi dalam jangka waktu lama, berasal dari keluarga yang memiliki riwayat kanker, faktor alamiah seperti usia, faktor kebersihan seperti keputihan yang dibiarkan, PMS, personal hygiene daerah genital, faktor pilihan seperti memiliki anak banyak lebih dari 5.

Sebuah penelitian menunjukkan faktor resiko menderita kanker serviks seperti berganti-ganti pasangan seks lebih dari 6 mitra seks, menggunakan pil kontrasepsi lebih dari 4 tahun. Sedangkan pendapat Nuranna (2011a) menggunakan pil kontrasepsi lebih dari 12 tahun. Menurut Soebachman (2011) salah satu faktor resiko kanker serviks adalah memiliki anak lebih dari 3. Rasjidi (2007) merokok dan defisiensi zat gizi juga dapat menjadi faktor penyebab kanker serviks.

Kanker serviks jarang terjadi pada wanita muda (usia 20 tahunan). Kanker ini cenderung terjadi pada wanita paro baya, sebesar 50\% kasus ditemukan pada wanita usia 35-55 tahun; 50\% lagi ditemukan pada wanita dibawah usia 35 tahun.

Kanker serviks timbul bukan karena kehidupan sehari-hari yang penuh resiko, kenyataannya kebanyakan perempuan yang menderita kanker serviks adalah mereka yang kehidupan sehari-hari tidak beresiko, seperti kegemukan, hipertensi, tidak pernah hamil, menderita diabetes, menstruasi pertama pada usia sangat muda.

Pada studi pendahuluan di Puskesmas Brangsong 2 Kecamatan Brangsong Kabupaten Kendal, pada 5 ibu yang telah melakukan pemeriksaan IVA ada 3 ibu dengan hasil pemeriksaan IVA positif, 2 diantaranya berusia lebih dari 40 tahun, ketiga 
ibu dengan hasil pemeriksaan IVA positif memiliki anak lebih dari 3, sedangkan ada seorang ibu yang sering melakukan spa vagina (douching) dikarenakan keputihan lebih dari 2 bulan, dan hasil pemeriksaan IVA positif. Empat dari kelima ibu tersebut tidak mengetahui cara perawatan daerah genital yang benar.

Di Puskesmas Kendal 1 Kecamatan Kendal Kabupaten Kendal juga telah mengadakan skrining / deteksi dini kanker serviks dengan metode IVA, pemeriksaan IVA sampai dengan bulan September 28 orang, dengan hasil IVA negatif 26 dan hasil IVA positif 2 orang.

Berdasarkan latar belakang diatas, maka peneliti tertarik untuk melakukan penelitian yaitu hubungan usia, paritas dan personal hygiene dengan hasil pemeriksaan IVA di Puskesmas Brangsong 2 Kecamatan Brangsong Kabupaten Kendal.

\section{METODE PENELITIAN}

Penelitian ini menggunakan rancangan cross sectional yaitu rancangan penelitian yang dalam melakukan pengukuran variabel independen (usia, paritas dan personal hygiene) dan variabel dependen (hasil pemeriksaan IVA) tanpa ada kunjungan ulang

Jenis penelitian "Deskriptif korelatif", yaitu penelitian yang bertujuan menjelaskan hubungan, memperkirakan, menguji berdasarkan teori yang ada (Nursalam, 2011).. Populasi sejumlah 86 orang. Dalam penelitian ini peneliti menggunakan tehnik Consecutive sampling sehingga 78 orang responden.Tempat penelitian di Puskesmas 2 Brangsong Kecamatan Brangsong Kabupaten Kendal.

\section{HASIL DAN PEMBAHASAN}

Berdasarkan hasil penelitian data yang diperoleh adalah sebagai berikut :

\section{Analisa Univariat}

a. Distribusi frekuensi usia

Tabel 1. Distribusi frekuensi usia

\begin{tabular}{ccc}
\hline Usia & Frekuensi & Persentase \\
\hline $20-40$ tahun & 39 & 50
\end{tabular}

\begin{tabular}{ccc} 
Lebih dari 40 tahun & 39 & 50 \\
\hline Jumlah & 78 & 100
\end{tabular}

Berdasarkan tabel 1 diatas jumlah usia responden 20 - 40 tahun sebanyak 39 responden sebesar 50\% sama dengan jumlah responden yang berusia lebih dari 40 tahun.

Pemeriksaan IVA sebaiknya dilakukan secara rutin pada wanita yang telah melakukan hubungan seksual, pemeriksaan IVA adalah cara paling mudah dan murah untuk mendeteksi secara dini kanker serviks.

Pemeriksaan ini dapat dilakukan kapan saja bahkan dalam siklus menstruasi, pada masa kehamilan, saat nifas atau paska keguguran. Pemeriksaan IVA juga dapat dilakukan pada wanita yang dicurigai atau telah diketahui IMS atau HIV / AIDS.

b. Distribusi frekuensi paritas

Tabel 2. Distribusi frekuensi paritas

\begin{tabular}{|c|c|c|}
\hline Paritas & Frekuensi & Persentase \\
\hline Rendah & 51 & 65,4 \\
\hline Tinggi & 27 & 34,6 \\
\hline Jumlah & 78 & 100 \\
\hline
\end{tabular}

Berdasarkan tabel 2 menunjukkan bahwa sebagian besar responden adalah yang memiliki paritas rendah sebesar sebanyak 51 responden $(65,4 \%)$.

Wanita yang pernah 3 kali atau lebih melahirkan sacara normal memiliki resiko kanker serviks lebih tinggi karena pada saat persalinan, janin akan melewati serviks dan menimbulkan trauma pada serviks (Soebachman, 2011).

c. Distribusi frekuensi personal hygiene Tabel 3. Distribusi frekuensi personal hygiene

\begin{tabular}{|c|c|c|}
\hline Personal Hygiene & Frekuensi & Persentase \\
\hline Baik & 68 & 87,2 \\
\hline Kurang & 10 & 12,8 \\
\hline Jumlah & 78 & 100 \\
\hline
\end{tabular}

Berdasarkan tabel 3 menunjukkan bahwa jumlah terbesar responden dengan personal hygiene baik sebanyak 68 responden $(87,2 \%)$. 
Penyebab utama penyakit kewanitaan seperti keputihan yang terus menerus yaitu: $10 \%$ imunitas tubuh yang lemah, 30\% kurangnya personal hygiene daerah genital dan 50\% lingkungan yang tidak bersih, 10\% faktor lain.

d. Distribusi frekuensi hasil pemeriksaan IVA

Tabel 4 Distribusi frekuensi hasil pemeriksaan IVA

\begin{tabular}{|c|c|c|}
\hline Hasil Pemeriksaan IVA & Frekuensi & Persentase \\
\hline Negatif & 39 & 50 \\
\hline Positif & 39 & 50 \\
\hline Jumlah & 78 & 100 \\
\hline
\end{tabular}

Berdasarkan tabel 4 menunjukkan bahwa hasil pemeriksaan IVA terbagi menjadi dua sama banyak antara yang negatif dan positif.

\section{Analisa Bivariat}

Analisis bivariat dimaksudkan untuk melihat hubungan Usia, Paritas dan Personal Hygiene dengan hasil IVA.

a. Hubungan Usia dengan Hasil

Pemeriksaan IVA

Tabel 5 Tabulasi Silang antara Usia dengan Hasil Pemeriksaan IVA

\begin{tabular}{|c|c|c|c|c|c|c|}
\hline \multirow{3}{*}{ Usia } & \multicolumn{4}{|c|}{ Hasil Pemeriksaan IVA } & \multirow{2}{*}{\multicolumn{2}{|c|}{ Jumlah }} \\
\hline & \multicolumn{2}{|c|}{-} & \multicolumn{2}{|l|}{+} & & \\
\hline & $\mathrm{f}$ & $\%$ & f & $\%$ & $\mathrm{~F}$ & $\%$ \\
\hline $20-40$ & 39 & $\begin{array}{c}100 \\
0\end{array}$ & 0 & 0,0 & 39 & $\begin{array}{c}100 \\
0\end{array}$ \\
\hline$>40$ & 0 & 0,0 & 39 & 25,8 & 39 & $\begin{array}{c}100, \\
0\end{array}$ \\
\hline $\mathrm{Jumlah}$ & 39 & 50,0 & 39 & 50,0 & 78 & $\begin{array}{c}100, \\
0\end{array}$ \\
\hline $\begin{array}{r}X^{2}= \\
70,051\end{array}$ & & & & & & \\
\hline
\end{tabular}

Tabel 5 menunjukkan bahwa responden dengan hasil pemeriksaan IVA negatif semuanya berusia 20-40 tahun, sebaliknya dengan hasil pemeriksaan IVA positif semuanya berusia $>40$ tahun. Menurut uji statistik Chi Square menunjukkan nilai $\mathrm{p}=0,00$ atau $\mathrm{p}<$ 0,05 , berarti $\mathrm{H} 0$ ditolak dan $\mathrm{H} 1$ diterima, disimpulkan bahwa ada hubungan bermakna antara usia dengan hasil pemeriksaan IVA.
Dari data diatas dapat disimpulkan bahwa hasil pemeriksaan IVA positif / kanker serviks jarang terjadi pada wanita muda (usia 20 tahunan). Kanker ini cenderung terjadi pada wanita paro baya, sebesar $50 \%$ kasus ditemukan pada wanita usia 35 - 55 tahun; 50\% lagi ditemukan pada wanita dibawah usia 35 tahun (Soebachman, 2011)

b. Hubungan Paritas dengan Hasil Pemeriksaan IVA

Tabel 6 Tabulasi Silang antara Paritas dengan Hasil Pemeriksaan IVA

\begin{tabular}{rcccccc}
\hline \multirow{2}{*}{ Paritas } & \multicolumn{2}{c}{ Hasil Pemeriksaan IVA } & \multirow{2}{*}{ Jumlah } \\
\cline { 2 - 5 } & \multicolumn{2}{c}{ Negatif } & \multicolumn{2}{c}{ Positif } & \multicolumn{2}{c}{} \\
\cline { 2 - 5 } & $\mathrm{F}$ & $\%$ & $\mathrm{f}$ & $\%$ & $\mathrm{~F}$ & $\%$ \\
\hline Rendah & 30 & 58,8 & 21 & 41,2 & 51 & 100,0 \\
\hline Tinggi & 9 & 33,3 & 18 & 66,7 & 27 & 100,0 \\
\hline J u m l a h & 39 & 50,0 & 39 & 50,0 & 78 & 100,0 \\
\hline $\mathrm{X}^{2}=$ & \multicolumn{2}{c}{$\mathrm{dk}=1$} & \multicolumn{2}{c}{$\mathrm{p}=0,05$} & & \\
3,625 & & & & & &
\end{tabular}

Tabel 6 menunjukkan bahwa responden dengan hasil pemeriksaan IVA negatif lebih banyak pada paritas rendah. Sebaliknya responden dengan hasil pemeriksaan IVA positif lebih banyak pada paritas tinggi. Menurut hasil uji statistik Chi Square menunjukkan nilai $\mathrm{p}$ $\leq 0,05$, berarti $\mathrm{H} 0$ ditolak dan $\mathrm{H} 1$ diterima, disimpulkan adanya hubungan bermakna antara paritas dengan hasil pemeriksaan IVA.

Memiliki banyak anak (lebih dari 5) menambah faktor resiko kanker serviks.

c. Hubungan Personal Hygiene dengan Hasil Pemeriksaan IVA

Tabel 7 Tabulasi Silang antara Personal Hygiene dengan Hasil Pemeriksaan IVA

\begin{tabular}{|c|c|c|c|c|c|c|}
\hline \multirow{4}{*}{$\begin{array}{l}\text { Personal } \\
\text { Hygiene }\end{array}$} & \multicolumn{4}{|c|}{ Hasil Pemeriksaan } & \multirow{3}{*}{\multicolumn{2}{|c|}{ Jumlah }} \\
\hline & \multicolumn{4}{|c|}{ IVA } & & \\
\hline & \multicolumn{2}{|c|}{ Negatif } & \multicolumn{2}{|c|}{ Positif } & & \\
\hline & $\mathrm{f}$ & $\%$ & $\mathrm{f}$ & $\%$ & $\mathrm{~F}$ & $\%$ \\
\hline \multirow[t]{2}{*}{ Baik } & 33 & 48 & 35 & 51 & 68 & 10 \\
\hline & &, 5 & &, 5 & & $\begin{array}{l}0, \\
0\end{array}$ \\
\hline \multirow[t]{2}{*}{ Kurang } & 6 & 60 & 4 & 40 & 10 & 10 \\
\hline & &, 0 & &, 0 & & $\begin{array}{c}0, \\
0\end{array}$ \\
\hline \multirow{2}{*}{$\begin{array}{l}\mathrm{J} u \mathrm{~m} \mathrm{la} \\
\mathrm{h}\end{array}$} & 39 & 50 & 39 & 50 & 78 & 10 \\
\hline & &, 0 & &, 0 & & $\begin{array}{c}0, \\
0\end{array}$ \\
\hline $\begin{array}{c}X^{2}= \\
0,115\end{array}$ & \multicolumn{2}{|c|}{$\mathrm{dk}=1$} & \multicolumn{2}{|c|}{$\mathrm{p}=0, \overline{73}$} & & \\
\hline
\end{tabular}


Tabel 7 menunjukkan bahwa responden dengan hasil pemeriksaan IVA negatif lebih banyak mempunyai personal hygiene kurang. Sebaliknya responden dengan hasil pemeriksaan IVA positif lebih banyak mempunyai personal hygiene baik. Menurut hasil uji statistik Chi Square menunjukkan nilai $\mathrm{p}=0,73$ atau $\mathrm{p}>0,05$, berarti H0 diterima, disimpulkan bahwa tidak ada hubungan antara personal hygiene dengan hasil pemeriksaan IVA.

Penyebab utama penyakit kewanitaan seperti keputihan yang terus menerus yaitu: 10\% imunitas tubuh yang lemah, $30 \%$ kurangnya personal hygiene daerah genital dan 50\% lingkungan yang tidak bersih, 10\% faktor lain.

\section{KESIMPULAN}

Dari hasil penelitian yang telah dilakukan terhadap $78 \mathrm{ibu}$ di Puskesmas 2 Brangsong Kecamatan Brangsong Kabupaten Kendal dapat ditarik kesimpulan sebagai berikut :

1. Karakteristik usia terbagi sama banyaknya pada usia 20 - 40 tahun dan usia lebih dari 40 tahun, lebih banyak paritas rendah (51\%), personal hygiene baik (68\%), hasil pemeriksaan IVA sama banyaknya antara hasil IVA positif dan hasil IVA negatif.

2. Ada hubungan bermakna antara usia dengan hasil pemeriksaan IVA.

3. Ada hubungan bermakna antara paritas dengan hasil pemeriksaan IVA.

4. Tidak ada hubungan antara personal hygiene dengan hasil pemeriksaan IVA.

\section{DAFTAR PUSTAKA}

Arikunto S. 2003. Prosedur Penelitian suatu Pendekatan Praktek. Rineka Cipta. Jakarta

Nuranna dkk. 2011a. Program Pencegahan Kanker Serviks "See and Treat ". FK. UI, Jakarta
. 2011b. Skrining kanker Serviks dengan IVA dan Model Aplikasi di Lapangan. FK. UI, Jakarta

Nursalam. 2011. Konsep dan Penerapan Metodologi Penelitian Ilmu Keperawatan. Salemba Medika, Jakarta

Rasjidi I. 2007. Panduan Penatalaksanaan Kanker Ginekologi. ECG, Jakarta

Samadi H P. 2011. Yes, I Know Everything about kanker serviks. Metagraf, Solo

Santhy M. 2011. Silent Killer Diseases. Javalitera, Jogjakarta

Soebachman A. 2011. Awas, 7 Kanker Paling Mematikan. Syura Media Utama, Yogyakarta

Sulistyaningsih. 2011. Metodologi Penelitian Kebidanan Kuantitatif-Kualitatif. Graha Ilmu, Yogyakarta

Yatim F. 2005. Penyakit Kandungan. Pustaka Populer Obor, Jakarta

Yuliatin I S. 2011. Cegah dan Tangkal Kanker Serviks. Tibbun Media, Surabaya 